\title{
Hollowing out Corporate CANada? Changes in the Corporate Network SINCE THE 1990s
}

WiLliam K. CARROLL

JEROME KLASSEN

Abstract. The recent spate of foreign takeovers once again raises the question of whether Canada's corporate elite is being "hollowed out" in a silent surrender to foreign-based transnational firms. Using data from a study of interlocking directorates among the largest corporations in Canada and the world for the years 1996 and 2006, this paper assesses whether recent changes in the Canadian corporate network indicate a process of hollowing out or the reproduction of a domestic elite within global circuits of capital.

Key Words: hollowing out; Canadian political economy; corporate network analysis; class; globalization; transnational corporations .

Résumé. La récente vague de rachat d'entreprises par des investisseurs étrangers soulève de nouveau la question: l'élite entrepreneuriale Canadienne n'est-elle pas en voie de démantèlement, sous forme de capitulation silencieuse, par les firmes multinationales basées à l'étranger? À partir des données d'une étude de l'entrelacement des conseils d'administration des plus grandes entreprises au Canada et dans le monde en 1996 et 2006, cet essai analyse les récents changements du réseau entrepreneurial Canadien afin de déterminer si il y a effectivement démantèlement, ou recréation d'une élite domestique au sein des circuits globaux de capitaux.

Mots clés: démantèlement; l'économie politique canadienne; analyse de réseau d'entreprise; classe; globalisation; firmes multinationales

\section{From Silent Surrender to Hollowing Out}

The issue of hollowing out has preoccupied Canadian social scientists since Kari Levitt's Silent Surrender: The Multinational Corporation in Canada - arguably the founding text of the New Canadian Political Economy (NCPE). Writing at the height of postwar American hegemony, Levitt argued that Canada's capitalist class was being converted, via 
foreign takeovers, into "an emasculated, if comfortable, business elite" lacking in entrepreneurship (1970:77). As American-based transnational corporations (TNCs) came to control more of the Canadian economy, the national corporate elite was transformed into a dependent class of branch plant managers, who administered units of transnational enterprise lacking in R\&D capacity. Moreover, the tendency for TNCs to serve only the domestic market (the "miniature replica" effect, Levitt 1970:135-7) and to export profits to foreign parents set Canadian capitalism on a course of regression to the status of a "rich hinterland" - a metaphor that subsequently became the touchstone of scholarship in the NCPE (Laxer 1973; Williams 1983).

Writing three decades later, Harry Arthurs (2000) presented a remarkably similar analysis, predicated on claims about the nature of transnational enterprise and the implications for Canada's capitalist class. Arthurs, however, noticed that, at the close of the 20th century, TNCs embraced a more complex international division of labour, according to which subsidiaries were often assigned world product mandates while parent firms exerted more direct control over them, in order to coordinate profit maximization for the entire enterprise. This development is the basis for his introduction of the term "hollowing out" of corporate Canada. From a study of 115 foreign-owned subsidiaries in Canada, compared at 1985 and 1995, Arthurs adduced several consequences of foreign control of large corporations, which add up to a process of hollowing out:

- A tendency, as foreign parents tighten control over subsidiaries, for the size of the board of directors to shrink and for the percentage of nonresident directors, chairs, and CEOs to increase;

- Diminishing autonomy for subsidiaries and less leverage for local management vis-à-vis the head office - as subsidiaries are subjected to closer oversight by relevant divisions of parent firms;

- A declining market for specialized producer services such as industrial R\&D and legal services, as core functions are relocated to head offices.

As parent companies assume tighter control of subsidiaries,

'Corporate Canada' - the community of directors and senior executives of Canadian domestic corporations and foreign-owned subsidiaries - is being 'hollowed out.' (Arthurs 2000:44)

Much like Levitt, Arthurs perceives a threat not only to the viability of Canada's capitalist class, but to the welfare of all Canadians: 
... each time a transnational corporation rejigs its organization chart, each time the role and structure of its subsidiaries is [sic] redefined, not just an enfeebled and vulnerable Corporate Canada but all Canadians are put at risk. (Arthurs 2000:45-6)

More recently, several high-profile foreign takeovers of large Canadian corporations have sharpened public concerns about this phenomenon, leading the federal government to establish a Competition Policy Review Panel to review investment and competition policies. In the midst of the debate, Mel Watkins, a longstanding proponent of Levitt's thesis, captured the transition in public sensibilities from the political economy of branch-plant capitalism to the political economy of hollowing out:

Once upon a time, Canadians had worried about being reduced to a branch-plant economy. Now we worry that the flight of head offices is leading to a "hollowing out" of corporate Canada and the Canadian economy. (2008: 14)

There is, however, a range of dissenting voices on this issue, just as there was concerning the original thesis of Silent Surrender (cf. Moore and Wells 1975; Carroll 1985). The Conference Board of Canada (2008) weighed in with a study that found that Canadian companies had outstripped foreign companies in international acquisitions from 1994 through 2007. A lengthy compendium of Statistics Canada findings on TNCs in Canada, released a few months earlier, noted that in recent years, "the effect of foreign takeovers has not been to reduce the number of head offices in Canada or head-office employment, but to create more head offices" (Baldwin and Gellatly 2007:8). The same report concluded that foreign-controlled firms in Canada are more likely than domestically controlled firms to use advanced technology, to have a research and development division, to show higher labour productivity and higher pay scales, and to diversify across industries. In another study, Jerome Klassen (2008) placed these kinds of findings in a global political-economic perspective and cited OECD (2006) data on the comparable ratio of foreign direct investment to GDP in Canada, France, Britain, and Germany. Noting that Canadian firms in diverse sectors have extensive foreign investments commensurate with global strategies for expansion and accumulation, Klassen concluded that "Canadian capital is the dominant force in the home market, and is independently imperialist vis-à-vis the world economy" (2008:11; see also, Klassen 2009). Bill Burgess (2000) and Paul Kellogg (2005) have offered similar theories of Canada as a core economic power within global circuits of capital. 
To date, however, the discussion on hollowing-out has been framed largely in terms of the microeconomics of firms, either with a singular focus on foreign ownership (as in Arthurs 2000) or with the distinction between domestic and foreign ownership serving as an independent variable (as in Baldwin and Gellatly 2007). A more sociological research tradition on networks of corporate power, however, has great relevance to this issue. Conceiving of social structure as a social network (Tindall and Wellman 2001:266) enables one to ask different questions, not simply about the statistical relations among variables in a causal model but about the substantive relations among the individuals and firms that comprise a corporate power structure. Sociological research on networks of interlocking corporate directorates has proliferated since the 1960s, and has established the ubiquity of national "corporate communities" bound together by such social relations (Domhoff 1980; Stokman et al. 1985; Windolf 2002). Although the precise significance of any particular directorate interlock is highly context dependent (Mizruchi 1996), the entire set of interlocks that constitute an intercorporate network serves to reinforce elite solidarity while enabling interfirm relations of communication, coordination, influence, and control (Carroll and Sapinski 2010). Canada has a rich tradition of scholarship in this field (Carroll 2008). Indeed, from the pioneering work of John Porter (1965) and Libbie and Frank Park (1973 [1962]) to more recent studies by Wallace Clement (1975, 1977) and William Carroll (1986, 2004), network analysis has been a mainstay of research on the social organization of corporate Canada.

A network perspective on hollowing out directs our attention to the effects of foreign ownership of large companies on the structure of the corporate elite. These effects might take shape along lines first identified by Wallace Clement. Inspired by R.T. Naylor's (1972) narrative of Canadian capitalist development as a process dominated by merchants and bankers uninterested in funding local industry, Clement posited that Canada's corporate elite showed an unusual disjuncture between finance and industry. Elite ties had failed to develop between Canadian-controlled financial institutions and Canadian-controlled industrial corporations (Clement 1975); instead, "continental connections" linking Canadian finance with US industry (Clement 1977) gave rise to a distinctive, comprador elite structure lacking the independent capacity for national development and world expansion.

Carroll's $(1986,2004)$ research, covering the period from 1946 through 1996, disputed these claims. Noting that Clement (1977:167) misinterpreted his own findings, which show stronger elite relations between industrial and financial capital in Canada than in the US (Carroll 1986:29), Carroll documented the reproduction, across half a century, 
of a national corporate network, centred around leading industrial and financial corporations owned and controlled in Canada (see also Brownlee 2005; Carroll 2007). This suggests an ongoing structural basis for what Domhoff (2006) calls a national corporate community. But Carroll's data end at yearend 1996, eight years after the implementation of the Canada-US Free Trade Agreement and barely three years into the North American Free Trade Agreement (NAFTA). The longer term ramifications of these continentalizing arrangements on the structure of the Canadian corporate elite have not been explored.

A study of the Dutch corporate network furnishes an instructive point of comparison. Observing the network in 1976, 1996, and 2001, Heemskerk finds a pattern of decline, particularly after 1996, in the corporate community, with the inner circle of interlocking directors partly disintegrating. Accompanying this decline has been a "flow of foreign influences":

foreign directors flood Dutch boards, English has become the common language, takeover defences are pulled down, and firms previously associated with some national pride have been sold to the highest foreign bidders.... (2007:162)

Although Carroll's (2004) most recent Canadian study did not discern a "flow of foreign influences," it did show much the same pattern of thinning in the old boys network, which Carroll attributed to a new regime of corporate governance in which multiple directorships are no longer the norm (cf. Heemskerk 2007:165). Yet despite the reduced incidence of interlocking, the Canadian network retained its basic coherence through the mid-1990s, leading to the conclusion that

... national business communities such as Canada's persist, held together by a range of factors, including the need to exercise hegemony locally and to access the business scan that interlocking directorates enable. (Carroll 2008: 57)

A key issue we take up here is whether in the ensuing decade a flow of foreign influences led the Canadian network to become disarticulated.

The Dutch case actually concords with an international literature suggesting that recent surges in economic globalization have induced a disarticulation of national corporate communities that is not at all unique to Canada (Scott 1997; Robinson 2004), as transnational corporations increasingly orient themselves not to their nominal domiciles but to the world market. Such disarticulation of national business elites suggests that a degree of "hollowing out" may be a general feature of capitalist globalization. For Arthurs, Watkins, and other proponents of the thesis 
of hollowing out, what distinguishes Canada from the Netherlands and other middle powers is not simply the "flow of foreign influences" and the trend toward thinning of the national corporate network, but the leitmotif of American domination. Therefore, any assessment of whether Canada's corporate elite is now being hollowed out in the sense implied by Arthurs must consider the weight of the American presence within corporate Canada.

The discussion so far suggests three sets of indicators of hollowing out, and three associated hypotheses. To the extent that corporate Canada has been hollowed out, we should find:

H1. A narrowing accumulation base for a corporate community in Canada, defined by: (a) increasing foreign (especially US) control of Canada's top corporations; and (b) the related conversion of Canadian subsidiaries of foreign-based parents into operating units directly integrated into the parent, truncating the structure of top management, as strategic functions are concentrated in the parent firm's head office.

H2. Disarticulation of the national corporate network, evident in: (a) weakened cohesion; and (b) increasingly extraverted (especially continental) relations. Although empirical evidence to 1996 runs against this interpretation, key continentalizing processes associated with NAFTA were barely underway by 1996 . Thus, the time frame most relevant to the hypothesis of hollowing out is after this date.

H3. Failing international competitiveness. From Levitt forward, there has been a prediction of regression to hinterland status, which Arthurs repeats. With head offices of the major corporate players no longer in Canada, the various services that surround such offices also decline, limiting opportunity for Canadian managers and companies to advance, and weakening the basis for an internationally competitive economy. In addition to aggregate economic statistics, this should be evident in a decreasing number of world-class corporations based in Canada.

In assessing the thesis of hollowing out, this study considers each of these as a working hypothesis.

\section{Method}

We used Carroll's (2004) data for yearend 1996 as our starting point, and replicated his methods in compiling data for yearend 2006. In each year, we analyze a "C250" set of firms headquartered in Canada, consisting of 
the largest 200 nonfinancial corporations (ranked by total revenue) and the largest 50 financial institutions (ranked by total assets). The main source for data on firm size, location of head office, and locus of national control was the Financial Post 500 listings, published in July 1997 and 2007. Data on board composition was drawn from the annual reports of the corporations, available at company websites or at the Mergent Online database. To maintain consistency throughout the analysis, we restrict ourselves to companies for which we were able to obtain complete data on firm size and board composition. In assessing the second part of $\mathrm{H} 2$, we combine the Canadian data with similar data for the world's 500 largest corporations ("G500”) at yearend 1996 and 2006, gathered by Carroll (2009). ${ }^{1}$

\section{FINDINGS}

\section{Is Corporate Canada's Accumulation Base being Hollowed Out?}

The hollowing out thesis asserts, in part, that foreign subsidiaries are losing the relative autonomy they enjoyed in the old regime of multinational enterprise. In the extreme case, the local board of directors is simply abolished, with the parent board becoming the directorate for the subsidiary, in effect eliminating the firm as a bona fide corporation. As of late 2006, British Columbia, New Brunswick, Nova Scotia, Prince Edward Island, and Québec had no residency restrictions on corporate directors, enabling firms incorporated in those provinces to be effectively governed by foreign-based boards (Tuzyk 2006).

One indicator of hollowing-out would thus be an increase in the total number of wholly owned foreign subsidiaries that qualify for our C250 in terms of size, but that lack directorates within Canada. Unfortunately, these cases are difficult to detect, since Canadian corporations are not legally required to make public the members of their boards of directors. Hence, the absence of information on board members does not necessarily mean that a Canadian board does not exist. Still, in 1996, of 48 completely foreign-owned nonfinancials large enough to be included in the Top 200, seven had no board data available. By 2006, of 51 such firms, 23 had no board data available. We cannot state with certainty that these firms had abolished their Canadian boards by 2006, but the trend appears to go in that direction.

1. In compiling each G500, Carroll employed the same criteria as ours for the C250, selecting the 400 largest nonfinancials (ranked by revenue) and the 100 largest financials (ranked by assets). See Carroll (2009) for details. 
Analysis of specific cases of firms in the C250 of 1996, which apparently were large enough to qualify for the C250 of 2006 but seemed to have abolished their Canadian boards in the interim, supports this inference. Eleven firms fit this description: IBM Canada, Pratt and Whitney Canada, Chevron Canada, General Electric Canada, Kraft Canada, Weyerhaeuser Canada, Lear Corp Canada, Toyota Canada, Nissan Canada, BP Canada Energy, and Unilever Canada. These firms were all wholly owned by foreign parents (the first seven in the US). ${ }^{2}$

Company websites for these Canadian subsidiaries and their parents reveal textual traces of hollowing out. In the case of Weyerhaeuser Canada, wholly owned since 1999 by US-based Weyerhaueser Company, Canadian operations (amalgamating Macmillan Bloedel, which Weyerhaeuser took over in 1999) are now fully integrated and managed from the US head office. Although Weyerhaeuser Canada continues to be registered as a Canadian firm, its executive is no longer located in Canada, and it does not appear to have a board of directors independently of its parent. General Electric Canada Inc. also appears now to be fully integrated with GE USA. Its website, which is a page within the parent's site, provides no independent reporting of Canadian results, although it presents GE Canada as a technologically innovative employer of 10,000 workers. Similarly, although Kraft Canada Inc. still has its corporate office in Don Mills, Ontario, employs 7100, and claims status as Canada's leading marketer of food products and food services, it reports no independent financial information, and does not appear to have a Canadian board. In the case of Nissan Canada, the Japanese parent began in the early 1990s to create a corporate structure for management of all North American assets. By yearend 2006, Nissan Canada was 38\% owned by Nissan Motor Company of Tokyo, with the rest apparently owned by Nissan North America. Based in Gardena, CA, until 2005 (when the company announced it would move head office to Nashville, to take advantage of lower real estate prices), the latter was formed in 1990 to coordinate the company's US, Mexican, and Canadian operations.

Signifying the new organization of transnational accumulation, we find a specific discourse in play on the home pages of these foreign subsidiaries. Consider these exemplars of corporate identity:

Kraft is an innovation leader in the Canadian marketplace. Consumer satisfaction through innovation is a critical component of the Kraft strategy in Canada. http://www.kraftcanada.com/en/about/Pages/KraftinCan$\underline{\operatorname{ada} . \operatorname{aspx}}$

2. Another two were missing board data in both years: Canada Safeway and Siemens Canada. 
GE has operated in Canada for over 100 years, beginning with the manufacturing facility in Peterborough, Ontario founded by Thomas Edison in 1892. Today, GE Canada has numerous major manufacturing facilities, sales and services locations across the country. http://www.ge.com/ca/en/

These units of transnational capital are in but not of Canada, the latter preposition having been common in the era of branch plants, as with Ford Motor Company of Canada. "In" suggests a transnational entity that is locally inserted - in but not of. Such constructions of corporate identity are consistent with the thesis of hollowing out: the notion of a distinctly "Canadian" corporate entity has been superseded by a fully global brand, which seamlessly extends into Canada.

These cases point to rationalizing changes in TNCs, which Arthurs attempts to grasp via "hollowing out." We find, among the C250 in both 1996 and 2006, some firms that fit Arthurs's narrative. Yet analyses of a few cases do not give us a comprehensive view of the changing composition of corporate Canada. In Table 1, we tabulate the C250, considering country of control, and including not only wholly owned foreign subsidiaries, but all firms under domestic or foreign control for which we were able to obtain directorate data. ${ }^{3}$ We find that the complement of such corporations controlled in Canada actually grew in the decade after 1996. The number of dominant corporations under US or Japanese control fell, in both industrial and financial sectors. The number of industrials controlled on the European continent rose slightly, as did the number of financial institutions controlled in Britain. Our focus on the network of

Table 1. National Control of C250 Companies

\begin{tabular}{lrrcc}
\hline \multirow{2}{*}{ Country of Control } & \multicolumn{2}{c}{ Top 200 Industrials } & \multicolumn{2}{c}{ Top 50 Financial Institutions } \\
& 1996 & 2006 & 1996 & 2006 \\
\hline Canada & 143 & 158 & 36 & 39 \\
US & 36 & 22 & 7 & 2 \\
UK & 3 & 4 & 2 & 5 \\
Other Europe & 6 & 8 & 4 & 4 \\
Japan & 7 & 4 & 1 & 0 \\
Other & 5 & 4 & 0 & 0 \\
\hline Total & 200 & 200 & 50 & 50 \\
\hline
\end{tabular}

3. Following Carroll (2004:223), the country in which controlling interest is held was assessed on the basis of the location of the largest block of shares. Widely held firms with no principal shareholder were considered to be controlled in Canada. In practice, the vast majority of foreign-controlled corporations are wholly or majority owned by their foreign parents (Carroll 2004). In addition to the sources mentioned in Carroll (2004), the online database FPInfomart.ca was a source of data on nationality of control in 2006. Since our study focuses in good part on the network of interlocking directorates, in constructing our $\mathrm{C} 250$ s we replaced any firms lacking board data with the next largest corporation in the Financial Post 500, creating equally sized judgment samples of 250 firms, with complete data. The data file is available from W. Carroll upon request. 
board interlocks requires us to include only firms for which we were able to obtain lists of board members; however, even if we add back into the analysis the foreign-owned firms for which we were unable to find directorate data, the complement of Canadian-controlled top industrials remains essentially unchanged over the decade (decreasing by 1 to 135).

For the thesis of hollowing out, these are sobering trends. They document the continuing presence of Canadian interests at the higher reaches of corporate power. A singular focus on firms that disappear from the C250 due apparently to transnational reorganization may exaggerate the hollowing out phenomenon, precisely because it leaves out of the picture the most dynamic aspects of capital accumulation. To grasp these dynamics, we need to model the accumulation process, following Marx (1954:585-9), as an ongoing concentration and centralization of capital. Capital concentrates as large firms plough their profits back into new investment; it centralizes as corporations acquire or merge with other major firms. In both cases, the result is an accumulation of capital within the very largest companies, enhancing their command over labour and nature.

\section{Turnover in the C250}

Carroll (1986) presents a method for tracking the most basic aspects of capital concentration and centralization among a group of large corporations. By cross-tabulating the $\mathrm{C} 250$ at two observation points, we can analyze the turnover in composition, as corporations rise into and disappear from the $\mathrm{C} 250$, altering the character of the Canadian corporate elite's accumulation base, and (potentially) its social organization. Our analysis of turnover in the $\mathrm{C} 250$ centres on the shamelessly mixed metaphors - top dogs, fallen angels and rising stars - in Table 2.

Table 2 Categories in the Analysis of Turnover

\begin{tabular}{|l|l|}
\hline \multicolumn{1}{|c|}{ C250 of 1996 } & \multicolumn{1}{|c|}{ C250 of 2006 } \\
\hline $\begin{array}{l}\text { Top Dogs } \\
\text { (in C250 in both 1996 and 2006) }\end{array}$ \\
\hline $\begin{array}{l}\text { Fallen Angels } \\
\text { (Disappear from C250 after 1996) }\end{array}$ & $\begin{array}{l}\text { Rising Stars } \\
\text { (Enter C250 after 1996) }\end{array}$ \\
\hline
\end{tabular}

These distinctions allow an assessment of the institutional stability of the corporate elite's accumulation base. The range, theoretically, is bounded on one end by a scenario in which top dogs entirely predominate: capital concentrates rapidly in the initially dominant firms, ensuring their continued dominance. At the other end, we could envisage a complete turnover, as 250 rising stars replace 250 fallen angels - due to 
relatively slow growth by the initially dominant firms as well as capital centralizations that result in the disappearance of these firms.

Carroll's study of transitions in Canadian corporate power provides a baseline for this assessment: between 1976 and 1996, 52.4\% of the 1976 C250 (27 financial institutions and 104 industrials) were replaced by different firms. In comparison, 48\% of the 1996 C250 (24 financials and 96 industrials) were replaced by 2006 . The turnover rate for the most recent decade is only slightly less than that for the two decades preceding it, suggesting ongoing volatility.

\section{Fallen Angels}

We first present a prospective analysis that focuses on the characteristics of firms that disappear from the C250 after 1996 - the fallen angels. We categorize these 120 firms in terms of whether they disappear in a centralization of capital, in a low rate of capital concentration, in bankruptcy or otherwise winding up, or through apparent hollowing out (i.e., the eleven cases listed above). Following this, we examine the rising stars that, by 2006, replace the fallen angels in the ranks of the C250. This retrospective analysis of the $2006 \mathrm{C} 250$ considers how the rising stars came to enter the $\mathrm{C} 250$ - by rapid concentration of capital, by centralization, or by a combination of the two. If there is a counteracting tendency to hollowing out, an "endogenous" dynamic of accumulation among leading Canadian capitalists, it should be evident in this latter analysis.

\section{Figure 1. Fate of Firms Leaving the Top 250 after 1996.}

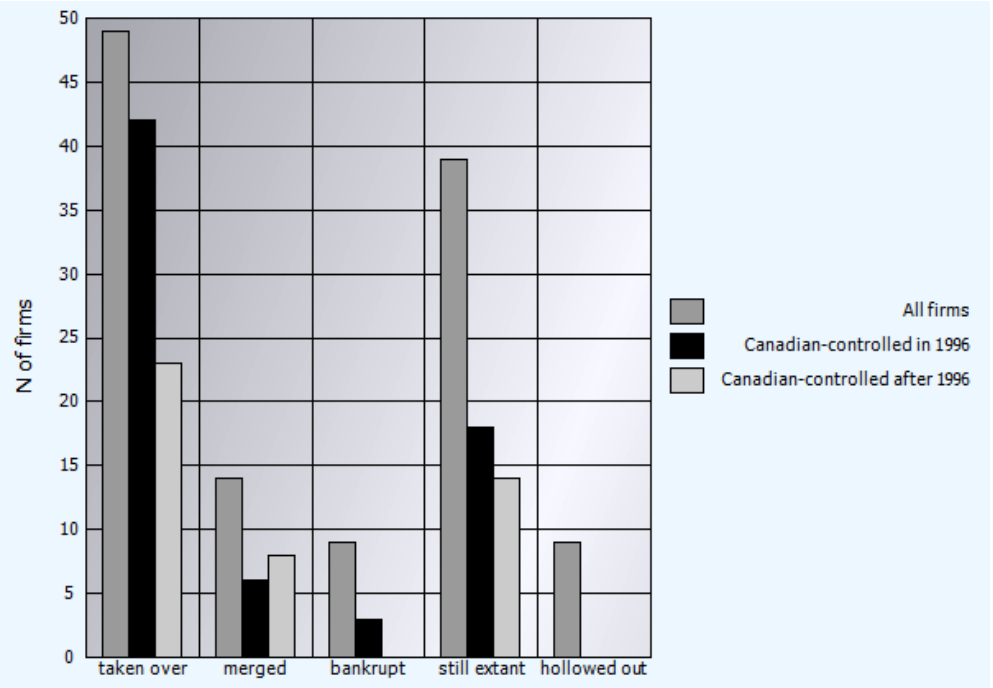


First, consider the fate of firms that leave the C250 after 1996. The dark grey bars in Figure 1 chart the fate of the 120 firms that disappeared from the C250 after the end of 1996; the black bars follow the subset of 69 firms that were controlled in Canada in 1996, but disappeared from the C250 thereafter; the light grey bars track the subset of 45 firms that were no longer in the $\mathrm{C} 250$ by yearend 2006, but that were controlled in Canada at that time. The graph depicts several specific fates for these 120 fallen angels. In all, 49 of them were taken over, and 42 of these were controlled in Canada in 1996. Considering the domicile of control of the acquiring firm, as of 2006 only 23 of the 49 were controlled in Canada. For the 14 firms that disappeared after 1996 in a "merger of equals" (i.e., a merger of two C250 firms), six were Canadian-controlled in 1996, and eight (i.e., four merged firms) were Canadian-controlled as of 2006. Combining these first two categories, we see capital centralizing both domestically and transnationally; but the net effect of angels falling is an increase in the number of foreign-controlled C250 firms.

Companies also disappear from the $\mathrm{C} 250$ by failing to accumulate capital at a competitive pace. In the extreme case, this leads to bankruptcy. Three of the nine firms that went bankrupt or were otherwise wound up were Canadian-controlled in 1996. More typical is the firm that remains in business but is no longer large enough to be included in the elite. Nearly a third of the firms that disappeared from the C250 after 1996 (39 in all) were still extant as companies at the end of 2006. Most were foreign controlled in 1996, but 18 were controlled in Canada at that point, and 14 were controlled in Canada at yearend 2006. ${ }^{4}$ The 11 apparent cases of hollowing out (firms whose 2006 directorates could not be ascertained) complete the tabulation.

In Table 3, we tabulate shifts in the "nationality" of capital for the 111 fallen angels that "survive" to 2006 in some form (i.e., they avoid bankruptcy). Of the 66 Canadian-controlled firms, 26 are subsequently taken under foreign control (whether through full-fledged centralization

Table 3 Country of Control for Fallen Angels from the C250 of 1996

\begin{tabular}{llcccc}
\hline & & \multicolumn{3}{c}{ Country of Control in 1996 } & Canadian- \\
controlled & US & Other & Total \\
\hline Country of & Canada & 40 & 4 & 1 & 45 \\
control as of & US & 16 & 21 & 2 & 39 \\
2006 & other & 10 & 2 & 15 & 27 \\
\hline Total & 66 & 27 & 18 & 111 \\
Percent & 59.5 & 24.3 & 16.2 & 100.0 \\
\hline
\end{tabular}

4. For these cases of firms in the $1996 \mathrm{C} 250$ and extant in 2006 but too small to qualify for the $\mathrm{C} 250$, nationality of control as of yearend 2006 was discerned using the FPInfomart.ca database. See footnote 3. 
of capital or through acquisition of controlling interest), with both US and other TNCs being active in this process. In contrast, control of only five firms is transferred from foreign to Canadian interests. The vast majority of fallen angels that were under foreign control in 1996 remain so subsequently. This prospective analysis reveals a net trend toward hollowing out: a firm under Canadian control in 1996 that subsequently exited the $\mathrm{C} 250$ had a $39 \%$ probability of coming under foreign control by 2006, but a fallen angel under foreign control in 1996 had only an $11 \%$ probability of becoming "Canadianized" by 2006. Among these 111 firms, Canadian control drops from $60-41 \%$. On balance, the trends paint a picture of decline, from the standpoint of Canadian capitalist control.

\section{Top Dogs and Rising Stars}

The complementary category to fallen angels is the 120 companies that replace them, entering the C250 as of 2006, not having been large enough (or in some cases even extant) in 1996. These are the rising stars. Together with the top dogs, these companies constitute the C250 of 2006. For top dogs, the country in which controlling interest was lodged, as of yearend 2006, is shown in the first row of Table 4.

Here, we see quite a different picture. Of the 130 firms that are in the C250 at both moments, the most institutionally stable component of the corporate elite's accumulation base, approximately $80 \%$ are controlled in Canada at both times. ${ }^{5}$ The top dogs are tenaciously controlled by Canadian interests.

Table 4. Corporate Survivorship (1996-2006) and Country of Control as of 2006

\begin{tabular}{|c|c|c|c|c|c|}
\hline \multirow[b]{2}{*}{ Corporate Survivorship } & & \multicolumn{3}{|c|}{ Country of Control in 2006} & \multirow[t]{2}{*}{ Total } \\
\hline & & Canadian-controlled & $U S$ & Other & \\
\hline \multirow{2}{*}{ Top dogs } & $\mathrm{N}$ & 105 & 15 & 10 & 130 \\
\hline & $\%$ & 80.8 & 11.5 & 7.7 & 100.0 \\
\hline \multirow{2}{*}{ Rising stars } & $\mathrm{N}$ & 92 & 9 & 19 & 120 \\
\hline & $\%$ & 76.7 & 7.5 & 15.8 & 100.0 \\
\hline \multirow[t]{2}{*}{ Total } & $\mathrm{N}$ & 197 & 24 & 29 & 250 \\
\hline & $\%$ & 78.8 & 9.6 & 11.6 & 100.0 \\
\hline
\end{tabular}

Strikingly, the rising stars are also overwhelmingly under Canadian control as of 2006, and most of the companies that rise into the C250 under foreign control are not controlled in the US; that is, the trend in foreign control of rising stars is not toward continentalization but toward

5. Moreover, a turnover analysis for the 130 top dogs (not shown here) revealed that the 110 firms under Canadian control in 1996 tended to retain the same country of control at a higher rate [93.6\%] than did the 13 US-controlled firms [76.9\%] or the 7 firms controlled elsewhere in 1996 [71.4\%]. 
multilateral internationalization. These rising stars are the firms particularly successful in accumulating capital. When we focus on them, the prospects for corporate Canada look more promising. This points up a serious limitation in the thesis of hollowing out. By focusing exclusively on foreign penetration and corporate reorganization, it discounts the dynamic of endogenous accumulation, through which the accumulation base of corporate Canada is constantly renewed. "Hollowing out" tends to assume a master narrative of regression to hinterland status, but the reality is more complex. Moreover, the relative lack of US-based expansion into the $\mathrm{C} 250$, in contrast to penetration by other foreign interests, means that the number of the latter actually overtake US-controlled firms in the accumulation base of the corporate elite. By 2006, 26 of the C250 are US-controlled, but 29 are controlled in other foreign countries, including 9 in Britain, 5 in the Netherlands, 7 in other European countries, and 4 in Japan.

The endogenous growth of Canadian capital is further demonstrated by recent data on manufacturing turnover and "greenfield investment" (expenditure on new factories and means of production). According to Baldwin and Gellatly (2007:25-6), the Canadian manufacturing sector experienced a rapid rate of turnover in the decade after 1988, with 40 percent of factories in 1997 representing new outlays of productive investment. Conversely, approximately 47 percent of factories in 1987 were no longer operative a decade later. Over this period, new entries into the manufacturing sector claimed a growing share of market activity, alongside existing firms who reinvested profits in a process of "expanded reproduction." While foreign firms exhibited a stronger tendency to expand via mergers and acquisitions, domestic firms were three times as likely to engage in greenfield investment and thus generated a new pattern of industrial expansion under Canadian control. These new forms of turnover, investment, and reinvestment in the manufacturing sector further qualify hollowing-out theory, which posits a causal link between foreign takeovers on the one hand and crowding out of Canadian producers on the other. The evidence - from analysis of the C250 and from aggregate economic statistics - suggests a more complex situation, in which Canadian capital has reinvented and reproduced itself in the context of new forms of international competition.

\section{Is the Canadian Corporate Network being Hollowed Out?}

The second aspect of hollowing out predicts a disarticulation of the national corporate network, as transnational management structures cen- 
tralize control within foreign parents. This should be evident in: a) weakened cohesion within the national network; and b) increasingly extraverted (especially continental) relations. The alternative hypothesis is one of continuing reproduction of a domestic corporate elite, not only in the accumulation base but in elite relations themselves.

The turnover in composition of the $\mathrm{C} 250$ has implications for these contrasting theses. In charting the Canadian corporate network through the era of the postwar boom - the high tide of nationally organized corporate capitalism - Carroll (1986:139) showed how top dogs under Canadian control formed a stable core for the network from the 1940s through the mid 1970s, with Canadian-controlled rising stars becoming integrated into that core over time. This synergy between capital accumulation and elite social organization served to reproduce an indigenous bloc of "finance capital" - an integrated network of industrial and financial firms under Canadian corporate control. The following two decades, according to Carroll (2004), witnessed a thinning of the network, as corporate governance reforms came to restrict the size of directorates and extent of interlocking. These trends, evident throughout the advanced capitalist world (Carroll and Sapinski 2010), are distinct from hollowing out. What can we say of the most recent decade, which was a period of extensive recomposition in the C250?

First consider, as a basic measure of network centrality, the mean number of directors that $\mathrm{C} 250$ firms share with other C250 firms (in network terms, the mean weighted degree of interlocking, [weighted by number of shared directors]). ${ }^{6}$ In a context of general decline in corporate interlocking (with the overall mean falling from 11.2 to 5.4 directorship interlocks per firm), the segment of the corporate network under Canadian control reproduces itself in much the way that Carroll found during the 1946-1976 years (see Figure 2). Consistently dominant firms controlled in Canada are especially central in both years, and rising stars controlled in Canada show relatively high centrality by 2006 . UScontrolled firms are relatively peripheral in 1996 and are almost entirely detached from the network by 2006. Rising stars controlled elsewhere remain peripheral to the network, but the 10 top dogs controlled outside North America are relatively central in 2006..$^{7}$ Overall, the network is centred around Canadian-controlled firms of long-established domin-

6. For discussion of degree and of other measures of network centrality, see Freeman (1979). Network analyses were performed using UCINET (Borgatti et al. 2002).

7. Closer analysis shows that the high mean degree is attributable to four firms: Dutchowned Shell Canada, British-owned Imasco, Inco (formerly Canadian-owned but taken over in 2006 by Brazil-based CVRD) and Teck Cominco (classified here as foreign controlled due to Sumitomo Metal Mining's minority stake). 
ance in the Canadian economy, much as it was during the postwar boom years, ${ }^{8}$ but the incidence of interlocking has been greatly reduced.

What particularly impresses is the initially low centrality of UScontrolled corporations, and the subsequent drop in such firms' centrality. This plunge can be seen as consistent with Arthurs' thesis of hollowing out, as foreign subsidiaries detach from the Canadian national network, yet it accords with a long-standing pattern of corporate elite formation, which has strongly favoured interlocking among Canadiancontrolled firms (Carroll 1986; 2004).

Figure 2. Mean Weighted Degree of Interlocking, Firms Grouped by Country of Control

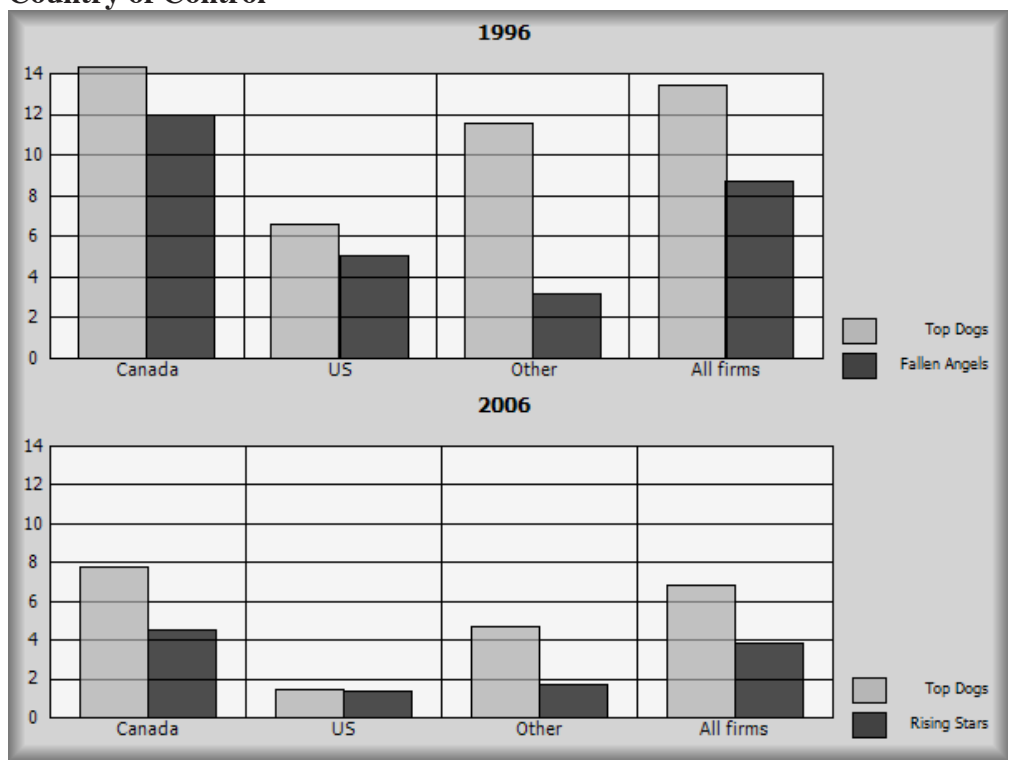

In contrast, for the Canadian segment of the elite, just as the accumulation of capital provides for a replenishment of Canada-based corporate capital, with fallen angels replaced by rising stars, the elite is continually recomposed as the latter are integrated into the network. In this way, capital accumulation and social organization intersect in the reproduction of a domestic corporate community. In this process of elite reproduction, top dogs play an important role, linking mainly with each other but also with rising stars. By 2006, the 103 top dogs that engage

8. The ETA ${ }^{2}$ statistic, a measure of the proportion of variance in the dependent variable that is explained by a categorical independent variable, indicates that the three categories of country of control account for $9.8 \%$ of variance in weighted degree of interlocking in 1996 and $8.3 \%$ in 2006. 
in interlocking tend to have other top dogs as their immediate contacts. On average, nearly two-thirds of their contacts (66.4\%) are composed of other top dogs, while $33.6 \%$ are composed of rising stars. Among the 92 rising stars that interlock in $2006,51.0 \%$ of their contacts are on average composed of top dogs. The tendency for top dogs to interlock with each other, reminiscent of the pattern discerned across 1946-76 by Carroll (1986:129-32), provides a further institutional source of stability within the Canadian corporate community.

The continuing prominence of Canadian interests in the corporate network is also reflected in the overall distribution of network centrality, as indicated by weighted degree of interlocking. Dividing that distribution into 50-firm quintiles, we find that in 1996 the most central quintile included only 5 foreign-owned firms ( 4 of them controlled in the US). By 2006 the complement of foreign-owned firms in the most central quintile had been reduced to 4, all of them controlled outside North America. The second-most central quintile showed a similar tendency, as its complement of foreign-controlled firms fell from 8 ( 5 of them US-controlled) to 4 ( 2 of them US-based). Thus, by 2006, only 8 of the 100 most central corporations in the network were controlled outside Canada.

In sum, analysis of corporate survivorship, both in terms of the changing accumulation base and the changing network, reveals more about hollowing out than does tracking the fate only of foreign-controlled subsidiaries, and leads to further qualification. Capitalist interests based in Canada continue to be at the centre of the corporate elite. Hollowing out seems restricted to a relatively few firms, most of which were already peripheral before the reorganization of transnational corporate management. Indeed, the result of hollowing out is a corporate community in which Canadian capitalist interests are all the more dominant. It is not corporate Canada that is being hollowed out, but rather, the strategic decision-making sites for certain foreign-controlled firms.

The second part of $\mathrm{H} 2$ predicts that as corporate Canada gets hollowed out the pattern of corporate interlocking becomes increasingly extraverted, and in particular, continental. That is, interlocks linking firms based in Canada to firms based elsewhere (and especially in the US) grow, relative to interlocks among Canada-based corporations. Such a prediction can be seen as a special case of the more general claim that as capitalism has globalized, national business communities have weakened and transnational corporate interlocking has proliferated (Scott 1997; Kentor and Jang 2004). We have indeed found a dramatic decrease in interlocking among the $\mathrm{C} 250$ Canadian corporations, which continues a trend discerned by Carroll (2004) across the 1976-1996 years. In fact, this tendency matches the trend in the global network, toward thinning of 
national networks and the expansion of transnational interlocking (Carroll 2009), especially within Europe and across the North Atlantic.

How does the developing pattern of elite social organization in Canada fit within this global context? To assess this aspect of $\mathrm{H} 2$, we combined our Canadian data with Carroll's data on interlocks among the largest 500 corporations of the world, in 1996 and 2006 respectively. Since some of the C250 Canada-based firms appear in the Global 500 (9 in 1996 and 15 in 2006), the resulting network comprises 741 corporations in 1996 and 735 in 2006.

In network terms, our question asks to what extent corporations domiciled in Canada show a tendency toward extraversion and away from introversion in their board interlocks. Absolute extraversion would entail a lack of any links to other Canada-based firms; absolute introversion would entail a complete preponderance of such interlocks. The greater the tendency to extraversion, the more we can reasonably conclude that the national network is becoming disarticulated, as Canadabased firms link into the global network rather than among themselves. Krackhardt and Stern's (1988) "External minus Internal (E-I) Index" is an appropriate indicator. For a given network segment (for present purposes, country of domicile), the index subtracts the proportion of all ties among segment members from the proportion of ties that bridge members and nonmembers. It ranges from -1, indicating that the segment is completely "introverted" to 1 , indicating that the segment is completely "extraverted." For a network segment in which half of all ties occurred among segment members and half occurred between members and nonmembers, E-I would be $0.5-0.5$, or zero.

Considering the Canadian 250, we find that from 1996 to 2006 E-I increases from -0.767 to -0.658 , indicating a slight shift toward extraversion, but a continuing predominance of interlocking among Canadabased firms. Considering only members of the Canadian 250 controlled in Canada, the index shows even greater introversion (in this context, ties among Canadian-controlled firms based in Canada), and the same slight shift toward extraversion (from -0.896 to -0.778). In each year, only a handful of Canada-based firms are net extraverts (E-I>0). In 1996, all nine were wholly owned subsidiaries of foreign-based TNCs, tied to parents rather than to the Canadian network. By 2006, there were, again, only nine Canada-based net extraverts, and all but one (Nortel Networks) were foreign-owned subsidiaries interlocked with their parents. Despite the reorganization of transnational enterprise highlighted in the hollowing-out thesis, a certain number of parent-subsidiary board relations persist, continuing the pattern reported by Carroll (2004) for 1976-96. Yet most of the C250 consists of Canadian-controlled firms 
that interlock mainly with each other and only secondarily with members of the G500 domiciled outside of Canada.

As formulated by Arthurs, the thesis of hollowing out, like Levitt's thesis of silent surrender, identifies as the trajectory for Canadian corporate management a profusion of US-Canada relations. The volume of interlocking across domiciles in the global network is therefore of some interest. In Table 5, we tabulate the total number of interlocking directors within and across countries and regions of interest. (Note that ROW - "rest of world" is an extremely diverse category, including all semiperipheral countries, i.e., states outside of the conventionally understood Triad of northern North America, western Europe, Japan and Australia.)

Table 5. Volume of Interlocking within and across Domiciles of the Global Corporate Network

\begin{tabular}{lrrrcc}
\hline \multicolumn{1}{c}{1996} & Canada & \multicolumn{1}{c}{ US } & Europe & Japan $/ O z$ & ROW \\
\hline Canada & 2790 & 62 & 44 & 18 & 0 \\
US & 62 & 1450 & 111 & 9 & 0 \\
Europe & 44 & 111 & 1774 & 21 & 1 \\
Japan/Oz & 18 & 9 & 21 & 356 & 0 \\
ROW & 0 & 0 & 1 & 0 & 18
\end{tabular}

\begin{tabular}{lcrrcc}
\multicolumn{1}{c}{2006} & Canada & \multicolumn{1}{c}{ US } & Europe & Japan/Oz & ROW \\
\hline Canada & 1344 & 46 & 73 & 3 & 6 \\
US & 46 & 740 & 104 & 3 & 5 \\
Europe & 73 & 104 & 1328 & 11 & 6 \\
Japan/Oz & 3 & 3 & 11 & 82 & 1 \\
ROW & 6 & 5 & 6 & 1 & 46
\end{tabular}

Comparing entries in the major diagonals, at 1996 and 2006, we see that the decline in the overall volume of interlocking in Canada matches trends elsewhere in the advanced capitalist zone. The decline in the total number of interlocks is especially severe in Japan, in part because its relative economic decline after the mid-1990s diminished the number of Japanese corporations big enough to qualify for the Global 500 (see Carroll 2009). Conversely, the increasing volume of interlocking among firms domiciled outside the Triad (ROW) reflects the growing number of such companies in the G500 (their ranks increase from 24 to 46).

For this study of corporate Canada, the entries of most interest lie in the first row/column of Table 5's matrices. What we observe among the C250 is a definite shift, away from ties to US and Japanese firms, and toward substantially more interlocking with European firms. In the Canadian 250, not only have firms controlled in Europe overtaken UScontrolled firms, but ties to European based firms have overtaken ties to US based companies, a reversal, in the post-NAFTA era, of what Clem- 
ent (1977) asserted as a long-standing tendency for the Canadian corporate elite to link primarily with the US elite.

Figures 3 and 4 give us the big picture of corporate Canada's articulation with the G500 network. These sociograms were created by implementing a spring-embedding solution (Freeman 2005:251) for the entire combined network of the C250 and G500. For present purposes, the spring-embedded solution places firms into a two-dimensional space where distances in the space come closest to reproducing the order of the proximities between firms in the network. ${ }^{9}$ These network maps can thus be read as graphic summaries of the actual configuration of relations among the largest corporations based in Canada and in the rest of the world: closeness in the sociograms indicates closeness in the actual network.

In both years, the Canadian network (with firms depicted as white nodes) is highly integrated, even among firms that engage in transnational interlocking (which are labeled with abbreviated corporate names), and it inhabits its own region of the combined network. Although the Canadian national network thins, this is in accordance with trends elsewhere - in the extreme, Japan (shown in dark grey), but also the US (shown in grey). Europe (shown in black) experiences increased interlocking, within the context of continuing EU integration. Overall, the number of Canadian firms with one or more transnational interlock increases from 46 to 61 . There is no tendency toward US-Canada elite integration; rather, as we saw in Table 5, ties between Canada and Europe are by 2006 more profuse than ties to the US. While in 1996 European ties were mainly the province of the Desmarais family's Power Corporation group, by 2006 there is a more diverse set of Canadian-based firms whose directors sit on European boards, including SNC Lavelin, Magna, Cascade, and Hydro Quebec. These firms are controlled in Canada, but others engaged in transnational interlocking show the classic relationship between parent and subsidiary (e.g., in 2006, Aviva Canada, AXA Canada, Honda Canada, Sony Canada, Wolsley Holdings, GlaxoSmithKline, Sears Canada, Apache Canada). Across the decade, the number of Canada-based firms interlocked with their foreign G500 parents holds steady at 16, but as we saw earlier, this figure omits apparent cases of hollowing out, in which Canadian subsidiaries no longer maintain their own boards of directors. On the other hand, the number of Canadian firms that are not foreigncontrolled subsidiaries but that engage in transnational interlocking in-

9. The algorithm began with a matrix of distances between pairs of firms (e.g., a pair of interlocked firms is said to be linked at a distance of one; a pair of firms not interlocked with each other but each interlocked with a common third firm has a distance of two in the network, etc.). Hence, the positions of points in the space loosely correspond with the distances between points in the network. 
creases from 30 to 45 , indicating that major capitalist interests based in Canada have raised their profile within the global corporate network.

Significantly, Europe's own extensive ties to the US make it clear that Canada-US “continental connections" (Clement 1977) simply form part of a North Atlantic elite network, as suggested by Carroll (1985:41-2).

Figure 3. Mapping of Corporate Interlock Network: Combined Canadian 250 and Global 500, 1996

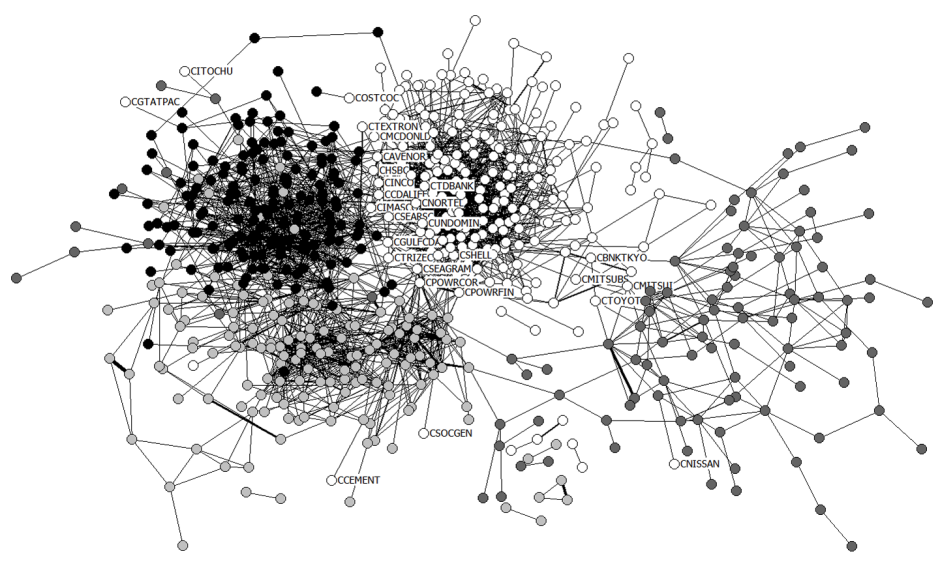

Figure 4. Mapping of Corporate Interlock Network: Combined Canadian 250 and Global 500, 2006

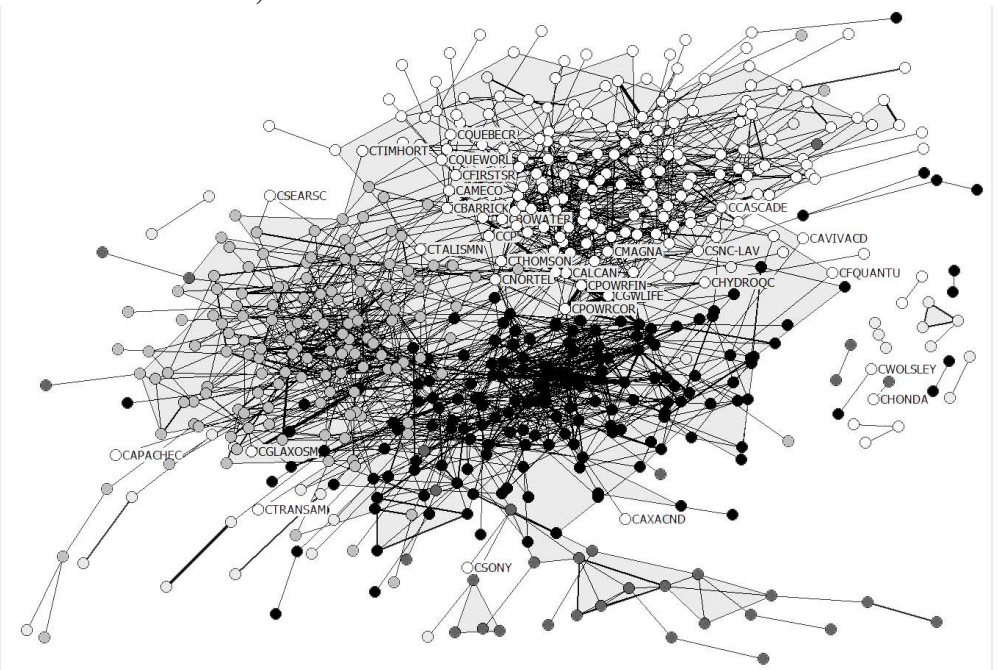

Key to Figures 3 and 4: white nodes: based in Canada; grey: based in the US; black: based in Europe; dark grey: based in Japan/Australia; light grey: based outside the Triad. Line thickness indicates the number of directors shared by a pair of firms. 
From this vantage point, we see a process of regional elite reproduction in the North Atlantic zone, not the hollowing out of corporate Canada. The global network itself is overwhelmingly centred on the North Atlantic, and with the decline of corporate Japan becomes even more so over the decade.

\section{Corporate Canada among the Global Giants}

$\mathrm{H} 3$, which views the decline of international competitiveness as a consequence of hollowing out, can be considered more briefly. Most immediately for present purposes, the impact of hollowing out should be evident in a decreasing number of world-class corporations based in Canada. In Table 6 we compare the presence of Canada-based corporations in the G500 of 1996 and 2006. Overall, contrary to the thesis of hollowing out, the Canadian complement grows from 9 to 15 , an increase of $66.7 \%$, which occurs both among financial institutions and nonfinancial companies. (The complement of US-based firms, meanwhile, falls from 167 to 158.) By yearend 2006, all 5 of Canada's big banks plus its largest life insurer number among the 100 largest financial institutions of the world; and 9 nonfinancials number among the world's largest 400 nonfinancials. All the firms listed in Table 6 were controlled within Canada at the time indicated, however three nonfinancials subsequently fell from the ranks of leading global corporations. Seagram disappeared into FrenchTable 6. Canada-based Firms in the G500, 1996 and 2006

\begin{tabular}{cll}
\hline Sector & \multicolumn{1}{c}{1996} & \multicolumn{1}{c}{2006} \\
\hline Financial & & \\
& Bank of Montreal & \\
& Bank of Nova Scotia \\
Canadian Imperial Bank of & Bank of Montreal \\
& Commerce & Cank of Nova Scotia \\
& Royal Bank of Canada & Manulife Financial \\
Nonfinancial & & Royal Bank of Canada \\
& & Toronto Dominion Bank \\
& BCE Inc. & \\
& & Alcan Inc. \\
& & BCE Inc. \\
& & Bombardier Inc. \\
& Nortel Networks & Encana Corp. \\
& & Magna International Inc. \\
& & \\
& & Onex Corporation \\
Seagram Co. Ltd. & Petro-Canada \\
George Weston Ltd. & Power Corp. of Canada \\
\end{tabular}


based Vivendi, in the failed attempt by the Bronfmans to diversify into a European foothold. Nortel never recovered from the dotcom crisis of 2000-2001, and is, at the time of writing, undergoing an ignominious dismemberment. In 2007, Alcan was taken over by British-based Rio Tinto, which is currently struggling to avoid its own bankruptcy. More than any process of TNC-driven hollowing out, these examples point to the increasingly crisis-ridden and volatile state of global capitalism, in which Canadian corporations play an increasingly important role.

This role is further evident in the data on foreign direct investment and Canadian direct investment abroad. According to Klassen (2009), the concentration and centralization of capital in Canada has created a base of accumulation for international expansion. Canada is home to approximately 1,400 TNCs, which operate approximately 3,700 foreign affiliates, employing more than one million workers. Since 1997 Canada has become a net exporter of direct investment capital, meaning that Canadian firms own assets abroad at a greater level than foreign firms in Canada. While foreign firms owned assets of $\$ 500.8$ billion in the Canadian economy in 2007, Canadian firms owned $\$ 514.5$ billion in world markets, shared out across the United States (44\%), Europe (28\%), the Caribbean (18\%), Asia (6\%), Latin America (5\%) and Africa $(1 \%)$. Canadian direct investment abroad is also distributed across industrial sectors, with finance accounting for $48 \%$, energy and mining $22 \%$, services and retailing $13 \%$, manufacturing $11 \%$, machinery and transport equipment $4 \%$, and wood and paper $2 \%$. These data indicate a growing and diversified stock of foreign assets held by Canadian firms, which have a global strategy for expansion and accumulation in key world markets, most notably in the United States and Europe. They suggest that Canadian firms are active in the cross-penetration of dominant capitals, whereby large corporations in the Global North expand into each other's national domains while also exporting capital to the Global South.

In this context, Canadian firms have largely maintained control over the vast majority of assets and operating revenues in the home market. In 2006 - the last year for which Statistics Canada (2009b) reports data foreign control of assets and operating revenues was $20.9 \%$ and $29.8 \%$ respectively, down from peak levels of $34.9 \%$ and $37.4 \%$ in 1971. Asset control by American and European firms is $11.5 \%$ and $6.6 \%$ respectively, while Canadian firms, along with the state, control $79.1 \%$ of total assets. While foreign asset control is highest in the manufacturing sector at $47.3 \%$, Canadian firms control a strong majority in every other sector, including $60.3 \%$ in mining, $63.8 \%$ in oil and gas, $90.8 \%$ in utilities, $95.4 \%$ in construction, $58.7 \%$ in wholesale trade, $77.6 \%$ in retail trade, $92.1 \%$ in transportation and warehousing, and $83.9 \%$ in finance and in- 
surance. The mining sector, which accounted for $0.7 \%$ of Canadian GDP in 2006 (Statistics Canada 2009a), is the only sector that registered a significant rise in foreign asset control from the previous year, moving from $11.9 \%$ to $39.7 \%$. No shift of this magnitude is evident in other, more strategic sectors of the economy, where recent trends are slight fluctuations around the sectoral data listed above. As a result, the evidence on foreign direct investment and foreign control is not commensurate with a theory of systematic hollowing out of corporate Canada. On the contrary, it demonstrates an internationalization of Canadian capital - and of Canadian capitalism - in the context of new forms of economic integration amongst the Triad zones of the world market.

\section{Conclusion}

The Canadian corporate community is more resilient than posited under the thesis of hollowing out. Although some wholly owned foreign subsidiaries, already marginal to, or isolated from, the national network in the postwar decades, appear to have become rationalized into the global operations of their parents - expressed discursively in the shift from being "of" to being "in" the host country - no general process of hollowing out has been underway. Rather, the ongoing restructuring of corporate capital is expressed, complexly, in the changing structure and composition of the dominant corporations and their interlocks. Some major Canadian firms have fallen from dominance, but concurrently, capital accumulating under Canadian control generates rising stars that take their places, not only in the structure of accumulation but in the elite network of interlocking directorates.

This investigation also confirms the analytic value of locating corporate Canada in a global and not simply "continental" context. We can reasonably assume that the same dynamics of concentration, centralization, and elite formation apply in other settings, reproducing national corporate communities even as each community becomes articulated into transnational practices of accumulation and corporate governance. Whether, in the process, a given national corporate community becomes weakened is an empirical question. In the case of Canada, the answer, for now, appears to be no.

When we place corporate Canada in a global context, metaphors like silent surrender and hollowing out seem one-sided. Rather than these rhetorical terms, concepts like uneven development and the cross-penetration of capital offer more promise of capturing the actual dynamics shaping corporate power in the contemporary world. The key difficulties with the 
hollowing-out metaphor, as with silent surrender before it, are that (1) it underestimates the resilience of Canada's own capitalist class; and (2) it misreads the dynamics of capital accumulation in an increasingly global field. Kari Levitt was, as subsequent research showed (Niosi 1981; Carroll 1986; 2004; Kellogg 2005), entirely wrong in her prediction that the Canadian capitalist class would become a powerless elite of branch plant managers and coupon clippers. She was equally wrong in projecting into the future the late-1960s hegemony of American capital, as in her prediction that by the year 2000 US-based corporations would control $75 \%$ of capitalist world output (1970:37).

Harry Arthurs repeats the first of Levitt's mistakes in assuming that what he calls hollowing out expresses Canada's "unique" engagement with globalization (2000:46). Although in recent years the number of corporate rising stars controlled in Canada far outweighs the number of foreign-controlled firms that appear to have been hollowed out, our qualitative case analysis did reveal some instances of the latter, along with an emergent business discourse that represents foreign subsidiaries of TNCs as "in" but not "of" Canada. Yet how unique to Canada is this phenomenon? It is of no small interest that when he considers the possible negative consequences of hollowing out, Arthurs's "instructive examples" are "Buffalo, St. Louis and Pittsburg - all of which have suffered the departure of head offices and of activities symbiotically related to them" (2000:45). These unintentionally ironic citations point us toward the deindustrialization and hollowing out of regional centres within US capitalism, a phenomenon that in the 1970s began to transform what had been the core of American industrial capitalism into a rust belt (Bluestone and Harrison 1982), even as union-free rising stars of the sunbelt came to take its place.

The analytic alternative to "hollowing out" emphasizes the uneven character of capital accumulation and the increasing cross-penetration of capital across the borders of countries where capital has achieved the capacity to pursue transnational accumulation strategies, whether the command of that capital is based in Canada, the US, China, or Brazil (Carroll 1985). For Canada, as we have seen, recent studies (published by Statistics Canada and by the Conference Board) tell the other side of the hollowing out story: foreign takeovers by Canadian capitalists more than compensate for increased foreign control of capital in Canada. With cross-penetration, each local ruling class, including the Canadian bourgeoisie, cedes some control of its home market, but as quid pro quo is able to accumulate capital more effectively outside that market. In these circumstances, "hollowing out" may describe actualities in each individual country, as in the disappearance of some directorates of wholly 
owned foreign subsidiaries. It is only when we widen the lens that we see a pattern of increasingly multilateral cross-penetration of capital, and corresponding consolidation of a transnational capitalist class, centred upon the North Atlantic, which includes Canada's leading businesses (Carroll 2009).

Indeed, as Sandra Halperin (2007) argues, the spread of capitalism has generally involved a spatialized dualism: a continuing process, under the control of trans-local elites, of hollowing out some areas and building up others - of uneven development in space. Governed by the changing contingencies of profit-making, uneven development occurs continuously within and between political jurisdictions (Harvey 2006). No place is immune, as "national institutions tie the mass of the local population to a bounded political and cultural realm ... [that] remains transected by trans-local classes" (Halperin 2007:551). Implicit in concepts like silent surrender and hollowing out is a one-sided view of capitalism that casts locals in the role of "victims," as in Arthurs' conclusion that hollowing out puts at risk "not just an enfeebled and vulnerable Corporate Canada but all Canadians" (2000:46). Typically, this diagnosis suggests a remedy that proceeds not from the bottom up, but as a statist intervention to create conditions for international competitiveness that will benefit "all Canadians" (cf. Gibson-Graham 1996).

Such nationalist projects often claim a "left" pedigree. However, it is unclear how, in a world where not only investments and trade but social injustices and ecological crises radically transect national borders, creating national champions and expanding the ranks of the organic intellectuals that deliver corporate capital's "producer services", within one territory, might contribute to a more democratic and sustainable human condition.

This question brings us to a final reflection. Our analysis shows corporate Canada making a shift from the US and toward Europe, in terms both of the source of incoming foreign investment and the pattern of transnational interlocking. Since Levitt's founding text, left nationalism in Canada has constructed its identity in opposition to American imperialism. What happens when American decline and the increasing cross-penetration of capital render the Other more multinational, when the threat to "all Canadians" issues from a multiplicity of nations? A key political implication of this study is that the association between the left and nationalism, always tenuous but sometimes defensible in the context of national oppression, needs to be radically rethought. Such reappraisal might consider whether bolstering the structures of capitalist ownership and management in Canada in order to promote robust accumulation for "all Canadians" has anything to do with projects of democratic re- 
form and transformation. In a process of rethinking, empirical analyses such as this one may contribute, however modestly, to bottom-up strategies for change. Knowledge of the capitalist class's trajectory in Canada might help popular movements engage with that trajectory more effectively in promoting alternatives to a global treadmill of production in which Canada's capitalists are holding their own.

\section{REFERENCES}

Arthurs, Harry W. 2000. The hollowing out of corporate Canada? Pp. 29-51 in Jane Jenson and Boaventura de Sousa Santos, eds., Globalizing Institutions: Case Studies in Regulation and Innovation. Burlington, VT: Ashgate Publishing Company.

Baldwin, J. and G. Gellatly. 2007. Global Links: Multinationals in Canada: An Overview of Research at Statistics Canada. Ottawa: Statistics Canada, Catalogue no.:11-622-MIE2007014.

Bluestone, B. and B. Harrison. 1982. The Deindustrialization of America. New York: Basic Books.

Borgatti, S.P., M.G. Everett, and L.C. Freeman. 2002. Ucinet for Windows: Software for Social Network Analysis. Harvard, MA: Analytic Technologies.

Brownlee, Jamie. 2005. Ruling Canada: Corporate Cohesion and Democracy. Halifax: Fernwood Publishing.

Burgess, Bill. 2000. Foreign direct investment in Canada: Facts and perceptions. The Canadian Geographer 44(2):98-113.

Carroll, William K. 1985. Dependency, imperialism and the capitalist class in Canada. Pp. 21-52 in Robert J. Brym, ed., The Structure of the Canadian Capitalist Class. Toronto: Garamond Press.

1986. Corporate Power and Canadian Capitalism. Vancouver: University of British Columbia Press.

2004. Corporate Power in a Globalizing World. Toronto: Oxford University Press.

2007. From Canadian corporate elite to transnational capitalist class: Transitions in the organization of corporate power. Canadian Review of Sociology 44(3):265-88.

2008. The corporate elite and the transformation of finance capital: A view from Canada. Sociological Review 56(S1):44-63.

2009. Transnationalists and national networkers in the global corporate elite. Global Networks 9(2):289-314.

Carroll, William K. and J.P. Sapinski. 2010. Corporate elites and intercorporate networks. In John Scott and Peter Carrington, eds., A Handbook of Social Network Analysis. London: Sage (in press).

Clement, Wallace. 1975. The Canadian Corporate Elite. Toronto: McClelland and Stewart. 
1977. Continental Corporate Power. Toronto: McClelland and Stewart.

Conference Board of Canada. 2008. Hollowing Out - Myth and Reality: Corporate Takeovers in an Age of Transformation. Ottawa: Conference Board of Canada.

Domhoff, G. William, ed. 1980. Power Structure Research. Beverly Hills, CA: Sage Publications.

2006. Who Rules America? Fifth edition. New York: McGraw Hill.

Freeman, Lynton C. 1979. Centrality in social networks: Conceptual clarification. Social Networks 1:215-239.

2005. Graphic techniques for exploring social network data. Pp. 248-69 in Peter J. Carrington, John Scott, and Stanley Wasserman, eds., Models and Methods in Social Network Analysis. Cambridge: Cambridge University Press.

Gibson-Graham, J.K. 1996. The End of Capitalism (As We Knew It): A Feminist Critique of Political Economy. Oxford and Cambridge, MA: Blackwell Publishers.

Halperin, Sandra. 2007. Re-envisioning global development: Conceptual and methodological issues. Globalizations 4(4):543-58.

Harvey, David. 2006. The Limits to Capital. Second edition. London: Verso.

Heemskerk, Eelke M. 2007. Decline of the Corporate Community: Network Dynamics of the Dutch Business Elite. Amsterdam: Amsterdam University Press.

Kellogg, Paul. 2005. Kari Levitt and the long detour of Canadian political economy. Studies in Political Economy 76:31-60.

Kentor, Jeffrey and Yong Suk Jang. 2004. Yes, there is a (growing) transnational business community: A study of global interlocking directorates 198398. International Sociology 19(3):355-68.

Klassen, Jerome. 2008. Hollowing out? Myth and reality. Relay: A Socialist Project Review 22(April-June 2008):8-11. 2009. Canada and the new imperialism: The economics of a secondary power. Studies in Political Economy 83:163-90.

Krackhardt D. and R. Stern. 1988. Informal networks and organizational crises: An experimental simulation. Social Psychology Quarterly 51:123-140.

Laxer, Robert, ed. 1973. (Canada) Ltd.: The Political Economy of Dependence. Toronto: McClelland and Stewart.

Levitt, Kari. 1970. Silent Surrender: The Multinational Corporation in Canada. Toronto: Macmillan of Canada.

Marx, Karl. 1954. Capital. Volume One. Moscow: Progress Publishers.

Mizruchi, Mark S. 1996. What do interlocks do? An analysis, critique, and assessment of research on interlocking directorates. Annual Review of Sociology 22:271-98. 
Moore, Steve and Debi Wells. 1975. Imperialism and the National Question in Canada. Toronto: privately published.

Naylor, R.T. 1972. The rise and fall of the third commercial empire of the St Lawrence. Pp. 1-41 in Gary Teeple, ed., Capitalism and the National Question in Canada. Toronto: University of Toronto Press.

Niosi, Jorge. 1981. Canadian Capitalism. Toronto: Lorimer.

Organization for Economic Cooperation and Development (OECD). 2006. OECD Factbook 2006: Economic, Environmental and Social Statistics. Paris: OECD, available at: http://www.sourceoecd.org/factbook/, accessed 24 September 2009.

Park, Libbie and Frank Park. 1973 (1962). Anatomy of Big Business. Toronto: James Lewis and Samuel.

Porter, John. 1965. The Vertical Mosaic. Toronto: University of Toronto Press.

Robinson, William I. 2004. A Theory of Global Capitalism. Baltimore: Johns Hopkins University Press.

Scott, John. 1997. Corporate Business and Capitalist Classes. New York: Oxford University Press.

Statistics Canada. 2009a. CANSIM II, table 379-0027, Gross domestic product (GDP) at basic prices, by North American Industry Classification System (NAICS), monthly (dollars), available at http://cansim2.statcan.gc.ca/ cgi-win/cnsmcgi.exe?Lang=E\&RootDir=CII $/ \&$ ResultTemplate $=$ CII/ CII_pick\&Array_Pick=1\&ArrayId=379-0027, accessed 24 September 2009. 2009b. Corporations Returns Act 2006. Ottawa: Statistics Canada.

Stokman, Frans N., Rolf Ziegler, and John Scott, eds. 1985. Networks of Corporate Power: A Comparative Analysis of Ten Countries. Cambridge: Polity Press.

Tindall, D.B. and Barry Wellman. 2001. Canada as social structure: Social network analysis and Canadian sociology. Canadian Journal of Sociology 26(3):265-308.

Tuzyk, John. 2006. Ontario considering changes to directors' residency requirements. Blake's Bulletin on Securities Law http://www.blakes.com/english/publications/bsra/v150/Bulletin150.pdf accessed 22 April 2009.

Watkins, Mel. 2008. Hollowing-out. Canadian Dimension 42(1):14-15.

Williams, Glen. 1983. Not for Export: The International Competitiveness of Canadian Manufacturing. Toronto: McClelland and Stewart Ltd.

Windolf, Paul. 2002. Corporate Networks in Europe and the United States. New York: Oxford University Press.

William K. Carroll is Professor of Sociology and Director of Social Justice Studies at the University of Victoria. His research interests include the political economy of corporate capitalism, the possibilities and challenges of counter- 
hegemony among contemporary social movements, and critical social theory and method. His book, The Making of a Transnational Capitalist Class, is forthcoming with Zed Books.

wcarroll@uvic.ca

Jerome Klassen is currently an Assistant Professor of Political Economy at the University of New Brunswick, Saint John. His research has been published in Studies in Political Economy, Development Forum, Labour/Le Travail and the Journal of Socialist Studies. In May, 2010, he will begin a two-year postdoctoral fellowship at the Center for International Studies at the Massachusetts Institute of Technology. As a postdoctoral fellow, he will be editing an anthology on the war in Afghanistan, and writing a book on the political economy of Canadian imperialism. Contact through www.jeromeklassen.ca. 